\title{
THOMAS PAINE AND ROBERT TREAT PAINE: A CASE OF MISTAKEN IDENTITY
}

\author{
BY MICHAEL L. LASSER
}

MR. LASSER is a member of the English Department of the Rutgers Preparatory School in New Brunswick.

7 HERE is a confusion, unusual in these days of precise scholarship, in the Thomas Paine bibliography, caused not by the authorship of the song, "Adams and Liberty," also known as "The Boston Patriotic Song," but by the errors which enabled the work to appear in two of the four complete editions of Thomas Paine's works. ${ }^{1}$ The real author of the song is Robert Treat Paine, Jr., a prominent Massachusetts Federalist, and the son of one of the signers of the Declaration of Independence. Robert Treat Paine, Jr., born in I773, was christened Thomas, and "Adams and Liberty," published in $\mathrm{I} 798$ by Thomas and Andrews, Boston printers, had printed at the top of the sheet, "By Thomas Paine, A.M."

Robert Treat Paine, Jr. legally took his father's name in I8OI. His older brother, the original Robert Treat Paine, Jr., had died of yellow fever in 1798 ; out of respect for his father the younger brother changed his name. Moreover, he did not want to encourage any relationship or confusion between himself and the well-known Deist. Thus, "he petitioned the legislature to allow him to assume a Christian name. ..." ".

The initial confusion was made by Thomas Clio Rickman, Thomas Paine's close friend. Rickman, a bookseller and minor poet about

1 The song is printed in:

Thomas Paine, Writings of Thomas Paine, ed. Moncure D. Conway (New York, I 896), IV, 486-487.

Thomas Paine, Life and Writings of Thomas Paine, ed. Daniel E. Wheeler (New York, c.1 908), X, 34I-345.

The song is not included in:

Thomas Paine, Life and Works of Thomas Paine, ed. William M. Van der Weyde, io vols. (New Rochelle, N.Y., c.1925).

Thomas Paine, The Complete Writings of Thomas Paine, ed. Philip S. Foner, 2 vols. (New York, c.1925).

2 Oscar G. T. Sonneck, The Star-Spangled Banner (Washington, I914), plate 12.

${ }^{3}$ Louis C. Elson, The National Music of America (Boston, 19oo), p. I83. 
whom not too much is known, was Paine's friend before his first trip to America. When Paine returned to England, he lived with Rickman and wrote, at the 7 Upper Marylebone Street address, Rights of Man, Part II, and "A Letter to the Addressers." Ten years later, in 1802 , when Paine, who had since lost his position and influence in the French government, returned to America, it was Rickman who bade him farewell from Le Havre. In his biography of Paine, written in 1819 , Rickman prints some previously unpublished poems by his friend, including "Adams and Liberty." He was obviously sure of its authorship because he did not print one poem which might have been written by Paine: "I have omitted the 'British Constitution,' not knowing it to be Mr. Paine's." ${ }^{4}$ G. Vale, who also wrote a strongly favorable biography of Paine, calls Rickman "what Boswell was to Johnson ... . with the best intentions he was not the man to do Mr. Paine justice."

Unfortunately, Moncure D. Conway, author of the standard biography of Paine and compiler of the standard edition of his works, saw fit to rely on Rickman, whom he found honorable and trustworthy, despite Vale's reservations and despite the evidence in Joshua Belcher's The Works of Robert Treat Paine, Jun., published eighty years before Conway's edition, which names Robert Treat Paine as the composer. Belcher notes that Robert Treat Paine wrote the song at the request of the Massachusetts Charitable Fire Departpartment to celebrate, in June, I 798, its fourth anniversary. He also wrote appropriate songs for five other Department anniversaries, the first, eighth, tenth, fifteenth, and one which is not dated. ${ }^{6}$

"Adams and Liberty," popular in both England and America, was Robert Treat Paine's most successful song. The tune, originally composed by John Stafford Smith for "To Anacreon in Heaven," was later used by Francis Scott Key for "The Star-Spangled Banner." Because the tune was so well-known, it was used by many poets, including Thomas Paine, on one occasion, and Robert Treat Paine, who wrote three other songs to the same tune. In addition, Thomas Paine may have been writing some poetry in France in I 798: "Poetry

4 Thomas Clio Rickman, The Life of Thomas Paine (London, 1819), p. 242.

5 G. Vale, The Life of Thomas Paine (New York, I 841 ), p. 4.

- Robert Treat Paine, Jr., The Works of Robert Treat Paine, Jun., Esq., ed. Joshua Belcher (Boston, 1812 ). 
too employed his idle hours, and he produced some fine pieces," wrote Rickman. ${ }^{7}$ After he had been forced out of the French government, he retired to the home of a friend, M. Bonneville. William Cobbett, a visitor, stated that Thomas Paine had written "several pieces of poetry," but Cobbett then crossed out the notation. ${ }^{8}$ When Richard Carlile, a friend of Rickman's and a supporter of Paine's, published a selection of Paine's poetry in $1819,{ }^{9}$ he did not include "Adams and Liberty." Thus the confusion was compounded.

The song was widely advertised and reprinted in New York and Boston, and, although there is no evidence, one wonders if Rickman somehow got a copy of The American Musical Miscellany or the Columbia Songster, ${ }^{10}$ in which the song was reprinted. Even if Rickman did see a copy or an advertisement, or if he did hear it sung in England, he should have known that Paine was in France while the song was being sung in London and New York. Moreover, Paine would hardly have praised Federalist John Adams, nor could he, by nature a loyal man, have felt so bitterly towards France. Although the song was written when war between France and the United States was imminent, Paine could not have written about a country whose citizenship he had chosen for himself, whose help for America's revolution he remembered, and in whose government he had served so faithfully:

While France her huge limbs bathes recumbent in blood And society's base threats with wide dissolution,

May peace like the Dove, who returned from the flood,

Find an ark of abode in our mild Constitution,

Moreover, it is almost impossible to imagine Paine naming a song after John Adams, who was in Paine's eyes an offensive blunderer. But Robert Treat Paine, a Federalist and an opponent of France, might easily write:

Let Fame to the world sound America's voice;

No intrigue can her sons from their government sever

Her pride is her Adams-his laws are her choice.

7 Rickman, p. 166.

8 Moncure D. Conway, The Life of Thomas Paine (New York, 1908), II, 334.

9 Thomas Paine, Miscellaneous Poems, ed. Richard Carlile (London, I819).

10 American Musical Miscellany (Northampton, Mass., I 798), p. 2 I I, and Columbia Songster (n.p., I799), Song lxiv. 
Finally, no biographer of Thomas Paine besides Rickman mentions the song, although a number of histories and bibliographies of American music, including those by Sonneck and Joseph Muller, another compiler of "The Star-Spangled Banner" bibliography, attribute it to Robert Treat Paine casually. Now that the musicologists have reported accurately, it remains only for readers and students of Thomas Paine to note the necessary adjustment of his bibliography.

\section{MILLIONTH ,VOLUME}

The millionth volume was received into the Rutgers University Library system at a short ceremony in the New Jersey Room during the morning hours of April r 2. A group of Library personnel, faculty and friends were in attendance. The volume, Anti-Slavery: The Crusade for Freedom in America by Dwight Dumond (1961), was accepted by Miss Anne C. Edmonds, Head Librarian of Douglass College. University President Mason Gross made the presentation. 